\title{
Lower oceanic crust formed at an ultra-slow-spreading ridge: Ocean Drilling Program Hole 735B, Southwest Indian Ridge
}

Paul T. Robinson, Henry J. B. Dick, James H. Natland, J. C. Alt, W. Bach, D. Bideau, J. S. Gee, S. Haggis, J. Hertogen, G. Hirth, P. M. Holm, B. Ildefonse, G. J. Iturrino, B. E. John, Deborah S. Kelley, E. Kikawa, A. Kingdon, P. J. LeRoux, J. Maeda, P. S. Meyer, D. J. Miller, H. R. Naslund, Y. L. Niu, J. Snow, R. A. Stephen, P. W. Trimby, H. U. Worm and A. Yoshinobu

Geological Society of America Special Papers, 2000, 349, p. 75-86,

DOI:10.1130/0-8137-2349-3.75

Ocean Drilling Program ODP Hole 735B, drilled on Legs 118 and 176, 1508 m of oceanic layer 3 on a transverse ridge adjacent to the Atlantis II Fracture Zone, Southwest Indian Ridge. The cored sequence consists predominantly or olivine gabbro and troctolite and lesser amounts of gabbro, and gabbronorite rich in oxides. The section contains live major blocks of relatively primitive olivine gabbro and troctolite, composed of many smaller igneous bodies. Each Of these composite blocks shows a small upward decrease in $\mathrm{Mg \#}$ [defined as $100 \times \mathrm{Mg} /\left(\mathrm{Mg}+\mathrm{Fe}^{2+}\right)$ ] and contains more fractionated Fe- and Ti-rich gabbros near the top.Small, crosscutting bodies of olivine gabbro and troctolite with diffuse boundaries may represent conduits through crystal mushes for melts migrating upward and feeding individual intrusions. Oxide gabbros and gabbronorites are commonly associated with shear zones of intense deformation, which crosscut the section at all levels, However, oxide-rich rocks decrease in abundance downward and are nearly absent in the lower 500 $\mathrm{m}$ of the section. The gabbros and gabbronorites appear to have formed from late-stage, Fe- and Tirich, intercumulus melts that were expelled out of fractionating olivine gabbros into the shear zones.

The fabrics of the recovered gabbros are consistent with synkinematic cooling and extension of the crustal section in a mid-ocean ridge environment. However, thick intervals of the core have only a weak magmatic foliation. The magmatic foliation is commonly overprinted by a weak, parallel, deformational fabric probably reflecting the transition from a largely magmatic to a largely crystalline state. Deformation in this crustal section decreases markedly downward.

Metamorphism and alteration also decrease downward, and much of the core has less than $5 \%$ background alteration. Major zones of crystal-plastic (ductile by dislocated creep) deformation in the upper part of the core probably formed under conditions equivalent to granulite-facies conditions when there was little or no melt present. Late-magmatic and hydrothermal fluids produced a variety of plagioclase, amphibole, and diopside veins. Late-stage, low-temperature veins of calcite, smectite, zeolite, prehnite are present in a few intervals.

The fact that the cored is unlike ophiolite as defined by the Penrose Conference Participants suggests that no ophiolite representing an ultra-slow-spreading-ridge environment like the Southwest Indian Ridge may be preserved. 